\title{
Input Issues in the Development of L2 French Morphosyntax
}

\author{
Anita Thomas
}

Citation: Thomas, Anita. 2021. Input Issues in the Development of L2 French Morphosyntax. Languages 6: 34. https://doi.org/10.3390/ languages 6010034

Received: 20 November 2020 Accepted: 16 February 2021 Published: 23 February 2021

Publisher's Note: MDPI stays neutral with regard to jurisdictional claims in published maps and institutional affiliations.
Department of Multilingualism and Foreign Language Education, University of Fribourg, CH-1700 Fribourg, Switzerland; anita.thomas@unifr.ch

\begin{abstract}
The aim of this article is to discuss the role of input characteristics in the development of French verb morphology. From a usage-based perspective, several cognitive and linguistic factors contribute to the ease or difficulty of processing input in L2 acquisition. This article concentrates on frequency, salience, and form-function association, factors that might influence what aspects of input are available to the learners' attention. A presentation of French verb morphology from this perspective shows how these factors can contribute to the use of the regular -er verb paradigm as a default. A review of empirical studies confirms the influence of input characteristics. The results suggest that the dominant pattern of regular verbs and the scarcity of salient clues from irregular verbs contribute to the specificity of L2 French development. The conclusion addresses the question of enriching L2 classroom input with irregular verbs. Such an input could facilitate the perception of form-function association, and thus, contribute to a more efficient development of French verb morphology. The article concludes by suggesting other ways of studying the influence of input as well as avenues for future research.
\end{abstract}

Keywords: input; SLA; French; morphosyntax; frequency; usage-based approaches

\section{Introduction}

This contribution to the special issue on the acquisition of French will focus on the role of input in the development of L2 French. This area of research has received a great deal of attention during the last 20 years. Studies have mainly been conducted within the usage-based approach, an approach that posits a close relationship between the language to which the learners are exposed and its representation as observed in learner production (Barlow and Kemmer 2000; Gass 2015). The work of Nick Ellis and colleagues has highlighted the interaction between cognitive factors, especially attentional processes, and linguistic factors, i.e., input characteristics of the target language, to explain the ease or difficulty of acquisition of a specific structure (Ellis 2006; Ellis et al. 2016). In this view, input is not the raw language found in native speakers but language as processed (Ellis 2006, p. 179). Accordingly, a target language does not appear to L2 learners as it is described in grammar books but rather in terms of input to L2 learners. This way of looking at language is important as a contribution to the understanding of L2 acquisition and even more to the improvement of L2 teaching.

Cognitive approaches to L2 acquisition have shown that working memory and cognitive processes related to attention play a crucial role in language processing and learning. Schmidt (2001) presented the basic assumptions of attention, which, besides controlling access to consciousness, is also limited and selective. His assertion that "SLA is largely driven by what learners pay attention to and notice in target language input and what they understand the significance of noticed input to be." (Schmidt 2001, pp. 3-4) is commonly accepted today (Ellis et al. 2016, p. 23).

Another important factor is of course the linguistic routines established in the L1 (and other well-mastered languages). The L1 plays a crucial role in the perception of the target language; L2 acquisition is "shaped by the L1" (Ellis 2006, p. 164). 
In this contribution, I will mainly focus on linguistic factors that interact with the attentional processes, making a specific phenomenon of the target language more or less available to the focus of attention, and thus, more or less available as input to the learner. Some of these factors are presented in the next section. Section 3 provides an introduction to French verb morphology. Section 4 provides a review of some studies that have examined the role of input in L2 French, especially in the acquisition of French verb morphology. Section 5 is devoted to a short conclusion and suggests other methods for studying the influence of input.

\section{Linguistic Factors and Input Characteristics}

This section is devoted to a short introduction of some linguistic factors that contribute to input processing: frequency, salience, and form-function association.

The factor input frequency is based on two types of calculations: token and type frequency (Bybee 2008). Token frequency corresponds to the number of occurrences in a given text, whereas type frequency corresponds to the number of items that participate in the same pattern, the number of items "that can fill a slot in a particular construction" (Behrens and Pfänder 2016, p. 9). These two ways of calculation tell us how often a linguistic item appears in the input (Ellis et al. 2016, p. 52).

Token frequency allows for the comparison of the frequency of different items, such as specific lexical items, lemmas, or morphemes in a given text or corpus. Token frequency has an effect on the level of lexical strength and of availability in memory of an item. The lexical strength of an item refers to its level of autonomy or connection to related items (Bybee 1995, 2008), for example the present tense "is" in relation to the infinitive "be." Importantly, the dominance of one form over other forms is not restricted to irregular paradigms; rather, it is the contrast between two or more forms in terms of token frequency that determines dominance.

Type frequency, on the other hand, has an effect on the productivity of a given pattern; a productive pattern might be used on novel items (Bybee 1995, p. 430). In L2 language acquisition, type frequency could explain the overextension of a given pattern on others, for example, the use of the regular past participle -é on irregular verbs such as prendre 'take,' which results in the production of pren[e] or prend[e] instead of pris. Type frequency is sometimes seen as the critical mass of input needed to acquire a specific pattern (Paradis 2010).

Another factor is salience, which is the degree to which an item "stands out relative to its context" (Ellis et al. 2016, p. 47). For this article, the most important issue is the low salience of grammatical function words and morphemes in L2 learning. Highly frequent function words, such as auxiliaries, may go unnoticed because of their phonological and semantic characteristics: they are unstressed and often perceived as redundant (for example, in the case of a compound past tense, the pastness is already given in an adverb or in the past participle). This results in incorrect productions of subject + non-finite form constructions (e.g., je parl[e] or je vu).

A third important factor is the form-function association (Ellis 2006; Ellis et al. 2016). This factor refers to the level of systematic association between a specific form and a specific function, or how reliably a specific morpheme is associated to a specific function. It can also be described in terms of probability: what is the probability that morpheme $\mathrm{x}$ corresponds to function $y$ ? The issue here concerns homophony and polyfunctionality. For example, the morpheme -s has many grammatical functions in English, including: 3rd person singular, 'he books a flight'; possessive, 'the book's cover'; and plural, 'three books.' This morpheme is a reliable plural marker, but it is not restricted to that function. This makes the $-s$ marker ambiguous, thus necessitating a larger context for disambiguation and interpretation.

Finally, semantic and distributional properties also play a role in input characteristics, although they are closely related to the factors mentioned above. For example, the aspect hypothesis is based on the distribution of past tense morphology according to the verb's 
semantic (lexical) aspect. In this view, the frequent association of imperfective with state verbs will make this association salient in the input to the learners (Andersen 2002).

These factors allow us to formulate hypotheses about the ease or difficulty with which a given item may be encountered, noticed, and possibly learned in L2 acquisition, since they reflect the regularities and irregularities in a given language. Research in psycholinguistics has shown that "language processing is sensitive to the statistical regularities of language experience at every level of structure" (Ellis et al. 2016, p. 279). Goldschneider and DeKeyser (2001) and Collins et al. (2009) are examples of studies that test the influence of input characteristics on the order of acquisition of L2 English. They both show that these characteristics "explain a substantial amount of acquisition difficulty" (Ellis 2006, p. 173).

A general hypothesis about the longitudinal development of French L2 morphosyntax was developed some time ago by Bartning and Schlyter (2004). It appears that French verb morphology is a challenge even at advanced stages (Bartning et al. 2009). As Prévost puts it, "adults learning L2 French seem to struggle with inflectional morphology" (Prévost 2009, p. 83). There is very little research about the role of French input characteristics on this L2 French developmental path, but there are some studies that address specific morphological issues. They will be reviewed after the next section, which will present French verb morphology.

\section{French Verb Morphology}

This section is devoted to an introduction to French verb morphology and a discussion of its characteristics in terms of L2 learner input.

Traditionally, French verb morphology is portrayed as illustrated in Figure 1. It seems that there is one specific form for each grammatical person in each tense. In the past, learners of French had to know these paradigms by heart and be able to recite je lis, tu lis....

\begin{tabular}{|c|c|c|c|}
\hline \multicolumn{4}{|l|}{ Indicatif } \\
\hline $\begin{array}{l}\text { Présent } \\
\text { je lis } \\
\text { tu lis } \\
\text { il lit } \\
\text { nous lisons } \\
\text { vous lisez } \\
\text { ils lisent }\end{array}$ & $\begin{array}{l}\text { Passé composé } \\
\text { j'ai lu } \\
\text { tu as lu } \\
\text { il a lu } \\
\text { nous avons lu } \\
\text { vous avez lu } \\
\text { ils ont lu }\end{array}$ & $\begin{array}{l}\text { Imparfait } \\
\text { je lisais } \\
\text { tu lisais } \\
\text { il lisait } \\
\text { nous lisions } \\
\text { vous lisiez } \\
\text { ils lisaient }\end{array}$ & $\begin{array}{l}\text { Plus-que-parfait } \\
\text { j'avais lu } \\
\text { tu avais lu } \\
\text { il avait lu } \\
\text { nous avions lu } \\
\text { vous aviez lu } \\
\text { ils avaient lu }\end{array}$ \\
\hline $\begin{array}{l}\text { Passé simple } \\
\text { je lus } \\
\text { tu lus } \\
\text { il lut } \\
\text { nous lûmes } \\
\text { vous lûtes } \\
\text { ils lurent }\end{array}$ & $\begin{array}{l}\text { Passé antérieur } \\
\text { j'eus lu } \\
\text { tu eus lu } \\
\text { il eut lu } \\
\text { nous eûmes lu } \\
\text { vous eûtes lu } \\
\text { ils eurent lu }\end{array}$ & $\begin{array}{l}\text { Futur simple } \\
\text { je lirai } \\
\text { tu liras } \\
\text { il lira } \\
\text { nous lirons } \\
\text { vous lirez } \\
\text { ils liront }\end{array}$ & $\begin{array}{l}\text { Futur antérieur } \\
\text { j'aurai lu } \\
\text { tu auras lu } \\
\text { il aura lu } \\
\text { nous aurons lu } \\
\text { vous aurez lu } \\
\text { ils auront lu }\end{array}$ \\
\hline \multicolumn{4}{|l|}{ Subjonctif } \\
\hline $\begin{array}{l}\text { Présent } \\
\text { que je lise } \\
\text { que tu lises } \\
\text { qu'il lise } \\
\text { que nous lisions } \\
\text { que vous lisiez } \\
\text { qu'ils lisent }\end{array}$ & $\begin{array}{l}\text { Passé } \\
\text { que j'aie lu } \\
\text { que tu aies lu } \\
\text { qu'il ait lu } \\
\text { que nous ayons lu } \\
\text { que vous ayez lu } \\
\text { qu'ils aient lu }\end{array}$ & $\begin{array}{l}\text { Imparfait } \\
\text { que je lusse } \\
\text { que tu lusses } \\
\text { qu'il lutt } \\
\text { que nous lussions } \\
\text { que vous lussiez } \\
\text { qu'ils lussent }\end{array}$ & $\begin{array}{l}\text { Plus-que-parfait } \\
\text { que j'eusse lu } \\
\text { que tu eusses lu } \\
\text { qu'il eût lu } \\
\text { que nous eussions lu } \\
\text { que vous eussiez lu } \\
\text { qu'ils eussent lu }\end{array}$ \\
\hline \multicolumn{4}{|l|}{ Conditionnel } \\
\hline $\begin{array}{l}\text { Présent } \\
\text { je lirais } \\
\text { tu lirais } \\
\text { il lirait } \\
\text { nous lirions } \\
\text { vous liriez } \\
\text { ils liraient }\end{array}$ & $\begin{array}{l}\text { Passé première forme } \\
\text { j'aurais lu } \\
\text { tu aurais lu } \\
\text { il aurait lu } \\
\text { nous aurions lu } \\
\text { vous auriez lu } \\
\text { ils auraient lu }\end{array}$ & $\begin{array}{l}\text { Passé deuxième forme } \\
\text { j'eusse lu } \\
\text { tu eusses lu } \\
\text { il eût lu } \\
\text { nous eussions lu } \\
\text { vous eussiez lu } \\
\text { ils eussent lu }\end{array}$ & \\
\hline
\end{tabular}

Figure 1. Conjugation table of the verb lire 'to read' on le conjugueur (https: / leconjugueur.lefigaro. $\mathrm{fr} /$ conjugaison/verbe/lire.html, accessed on 20 February 2021). 
French verb conjugations are categorized as regular or irregular and grouped according to the form of the infinitive. The relationship between the infinitive and the other forms is usually emphasized in conjugation tables. For example, the very popular tool le conjugueur (https: / / leconjugueur.lefigaro.fr, accessed on 20 February 2021), edited by the French newspaper Le Figaro, underlines that grouping the verbs according to the infinitive form will facilitate the memorization of the morphological endings ${ }^{1}$. The verbs are distributed into three groups (https:/ /leconjugueur.lefigaro.fr/frlesgroupes.php, accessed on 20 February 2021), the first being those ending in -er, except aller, the second being those ending in -ir for which the present participle ends in -issant (like finir), and the third group being all other verbs, labeled as "irregular." This third group is again split into four subgroups: verbs ending in -ir, verbs ending in -oir, and verbs ending in -re. The verb aller is in a subgroup of its own.

However, contrary to le conjugueur's claim, except for the group of -er verbs, the relationship between the infinitive and other forms is unpredictable, even though there are some recurrent patterns, as illustrated in (1) with two irregular verbs.

\begin{tabular}{rcccc}
\hline (1) Infinitive & Present Singular & 2nd Present Plural & Past Participle & Future Tense \\
\hline tenir 'hold' & tiens $/ \mathrm{t}$ & tenez & tenu & tiendrai \\
venir 'come' & viens/t & venez & venu & viendrai \\
\hline
\end{tabular}

The attentive reader will notice that verbs ending in -ir appear sometimes as regular ( \pm 300 verbs) and sometimes as irregular ( \pm 100 verbs). A closer look at verbs in these groups reveals how arbitrary these delimitations can be. As illustrated in Table 1, the number of similarities between many of these verbs is striking. This distinction between regular and irregular verbs ending in -ir might be confusing for L2 learners.

Table 1. Comparison of regular and irregular -ir verbs.

\begin{tabular}{|c|c|c|c|c|c|}
\hline $\begin{array}{l}\text { Regular -ir } \\
\text { infinitive }\end{array}$ & 2nd present plural & past participle & $\begin{array}{l}\text { Irregular -ir } \\
\text { infinitive }\end{array}$ & 2nd present plural & past participle \\
\hline $\begin{array}{l}\text { asservir } \\
\text { 'enslave' }\end{array}$ & asservissez & asservi & $\begin{array}{l}\text { servir } \\
\text { 'serve' }\end{array}$ & servez & servi \\
\hline $\begin{array}{l}\text { répartir } \\
\text { 'distribute' }\end{array}$ & répartissez & réparti & $\begin{array}{c}\text { partir } \\
\text { 'leave' }\end{array}$ & partez & parti \\
\hline $\begin{array}{l}\text { ressortir } \\
\text { 'coming from' }\end{array}$ & ressortissez & ressorti & $\begin{array}{c}\text { ressortir } \\
\text { 'go out again' }\end{array}$ & ressortez & ressorti \\
\hline
\end{tabular}

Moreover, from a morphological point of view, the distinction between "regular" and "irregular" is intricate in French. In fact, the morphemes corresponding to a specific tense, for instance imparfait or future tense, are the same for all verbs, as shown in Table 2. The irregularity lies in the stem alternation but not in the endings; for a discussion, see (Meunier and Marslen-Wilson 2004, p. 574ff.).

Table 2. Examples of stem alternation and regular endings.

\begin{tabular}{ccccc}
\hline Infinitive & Imparfait Stem & and Endings & Future Stem & and Endings \\
\hline être 'be' & ét- & & ser- & \\
faire 'do' & fais & -ais & fer- & $-a i$ \\
parler 'speak' & parl- & $-a i s$ & parler- & partir- \\
partir 'leave' & part- & $-a i t$ & pas \\
répartir 'distribute' & répartiss- & $-i o n s$ & répartir- & $-a$ \\
vendre 'sell' & vend- & $-i e z$ & vendr- & $-o n s$ \\
prendre 'take' & pren- & $-a i e n t$ & prendr- & $-e z$ \\
voir 'see' & voy- & & verr- & $-o n t$ \\
boire 'drink' & buv- & & boir- & \\
\hline
\end{tabular}

\footnotetext{
1 Les groupes sont un bon moyen de catégoriser les verbes pour retenir plus facilement leurs terminaisons.
} 
From a usage-based approach, "regularity" has to do with the number of items participating in a similar schema; in other words, with the kind and strength of frequency that applies to the verb. From this point of view, there are three main groups of verbs in French:

1. The four very irregular and frequent verbs être 'be,' avoir 'have,' aller 'go,' and faire 'do.' These verbs are characterized by a high token frequency. Their paradigms consist of many suppletive forms but also of some regularities (see Table 2). They are all used as auxiliaries (faire in very specific contexts as in se faire couper les cheveux 'get a haircut'), and all of them are semantically very open or at least polysemous (for example the usage of aller as 'go' and 'be [fine]'). Constructions with faire can describe most actions and replace action verbs (faire un plongeon 'take a dive,' plonger 'dive').

2. The regular verbs ending in -er in the infinitive (parler 'speak'). This is the most regular and productive verb conjugation. Its pattern is very high in type frequency: $90 \%$ of French verbs follow this pattern (more than 6000 verbs according to le conjugueur). The domination of these verbs in the French verbal system has many implications for the learners' interlanguage, as we will see in the next section.

3. The other verbs. As discussed above, there are patterns of regularity in this group of verbs; however, compared to the pattern of the -er verbs, they are quite low in type frequency. This makes most of these verbs generally low in both type and token frequency.

In order to discuss the role of salience and form-function association in the acquisition of L2 French verb morphology, it is important to stress the significant differences between the number of different forms in written and spoken modes. For example, for the verb lire in present tense singular (Figure 1), the forms are distinguished orthographically as lis and lit, but they are homophonous in spoken language and both pronounced /li/. In French, the relationship between sounds and letters is opaque. Written and spoken French can practically be considered as two different languages. This difference creates difficulties for all learners of French, both L1 (written) and L2 alike; for example, see (Fayol and Jaffré 2008).

French spoken verb morphology is strongly characterized by homophony. Homophony is especially frequent in the -er verbs and affects the most basic forms used in spoken French, as illustrated in Table 3 with the example of the verb donner 'to give.' For these verbs, there is one form for the present tense singular and 3rd person plural and one form for the present tense 2nd person plural, the infinitive, the past participle, and the imparfait (imperfective past) (Walter 1982 for the similarity between [e] and [ $\varepsilon]$ ). Hence, the non-finite forms and two past tense forms are consistently expressed with a form ending in [e]. In other words, there are two main forms for the regular verbs: one for the present tense (which is also the base form, on which the other forms are constructed) and one for the non-present tense. It is important to recall that the use of the 1st person plural is quite rare outside the French language classroom and usually replaced by the impersonal 3rd person singular on 'one' (Giroud and Surcouf 2016). The opposition between present versus non-present tense could be so salient both semantically and phonologically that it overshadows other phonologically perceivable oppositions up to an advanced level of proficiency.

For comparison, Table 3 also presents the forms for the irregular verb lire 'read.' Unlike the regular -er verbs, the differences between the various forms of an irregular verb are phonologically distinctive, and, as already mentioned, the relationship between the infinitive and the other forms is unpredictable for most of the irregular verbs.

Another important difference between regular and irregular verbs is that the 3rd person plural is distinct from the 3rd person singular in many irregular verbs. However, the homophony between the 2nd person plural and the imparfait applies to all verbs except a few (namely, être 'be,' dire 'say,' and faire 'do'). 
Table 3. Main forms in spoken and written French with the examples of donner 'give' and lire 'read.'

\begin{tabular}{ccc}
\hline Tense & $\begin{array}{c}\text { Regular -er Verbs } \\
\text { /Spoken/ and Written Forms }\end{array}$ & $\begin{array}{c}\text { Irregular Verbs (Example) } \\
\text { /Spoken/ and Written Forms }\end{array}$ \\
\hline $\begin{array}{c}\text { present singular } \\
j e, \text { tu, il/elle, on } \\
\text { 'I, you, s/he, one' } \\
\text { present 3rd plural } \\
\text { ils/elles 'they' } \\
\text { present 2nd plural } \\
\text { vous 'you' } \\
\text { infinitive } \\
\text { past participle } \\
\text { imparfait }\end{array}$ & /don/ donne/s/nt'give(s)' & /li / lis/lit 'read(s)' \\
& /done/ donnez 'give' & /liz/ lisent 'read' \\
/done/ / donner 'to give' & /lize/ lisez 'read' \\
\hline
\end{tabular}

In conclusion, the strong pattern of the regular -er verbs meets all the criteria as a candidate for a default pattern that might be used on other less frequent patterns (and verbs): the pattern has a high type frequency and the difference between the main present tense forms and the other forms is highly salient as well as consistent and reliable on the level of form-function associations. How this morphological system impacts the development of L2 French verb morphology is the subject of the next section.

\section{Effects of French Input and the Development of L2 French Verb Morphology}

This section is devoted to a review of studies that have addressed the influence of input on different aspects of the French morphological system in L2 acquisition: (1) the use of default forms in the present tense and infinitive contexts, (2) the development of the 3rd person plural, and (3) the development of the past tense.

\subsection{Default Forms in L2 Spoken French}

As described in the previous section, the pattern of -er verbs consists of two main forms, a 'short' form corresponding to the present tense and a polyfunctional 'long' form resembling the infinitive ([e] form). Example (2) (Thomas 2009, p. 12) illustrates the correct and incorrect use of the two forms, both in a present tense context ( $2 a$ and c) and in an infinitive context ( $2 b$ and $d$ ). The use of these forms as default forms in L2 French (spoken) production has been reported in many studies (e.g., Bartning and Schlyter 2004; Perdue 1993; Prévost 2009; Prévost and White 2000). They indicate that L2 learners' production is characterized by variability.

\begin{tabular}{|c|c|c|}
\hline \multirow[t]{6}{*}{ (2) } & a. & elle mange \\
\hline & & 'she eats' present tense context-correct \\
\hline & b. & les hommes va parle \\
\hline & & 'the men will speaks' infinitive context-incorrect \\
\hline & c. & il dans[e] \\
\hline & d. & $\begin{array}{l}\text { 'he dance' present tense context-incorrect } \\
\text { deux personnes va voyag[e] } \\
\text { 'two people will travel' infinitive context-correct }\end{array}$ \\
\hline
\end{tabular}

In her research on the influence of input in L2 acquisition at beginner/intermediate levels, Thomas (2009) addressed the question whether there is any systematicity in the production of these forms or whether it is arbitrary. She developed two hypotheses that posit a relationship between input and learner production. The first hypothesis was based on a traditional preexisting semantic categories approach in which the lexical aspect of the verbs would influence the input treatment and the learners' production. According to this hypothesis, specific forms are more relevant to the inherent lexical/semantic aspect of the verbs than others (see the Aspect Hypothesis, Andersen 2002; Andersen and Shirai 1994). The learners will first produce the forms that correspond to the prototypical lexical aspect 
of the verbs: present tense forms for the stative verbs (verbs that describe a state, e.g., be, live in, like, love) and past tense forms for the dynamic verbs (verbs that describe an action, e.g., work, buy, win a race).

Thomas' second hypothesis was based on a usage-based approach, according to which the learners will produce the most frequent form of a given verb in the input (Bybee 1995, 2008).

The study concentrated on infinitive and present tense for 12 common regular -er verbs. The frequency of forms of these verbs in the input was established empirically with data from a range of spoken French corpora that reflected the different kinds of French language to which the learners could be exposed:

1. Data from the French database C-ORAL-ROM (Cresti and Moneglia 2005);

2. Data from adult native speakers of French in conversation with adult classroom learners of L2 French (4 recordings of $60^{\prime}$ each and 25 recordings of 20-30' each);

3. Thirty-nine recordings of classroom teaching (Flyman Mattsson 2003);

4. One textbook used at beginner level.

The compilation included all the forms presented in Table 3 (above). The results showed a strong overlap between the two hypotheses in the input data. The stative verbs were very frequent in the present tense form, while the dynamic verbs were frequent in the [e] form, an opposition that had previously been documented in most studies on lexical aspect in French (e.g., Labeau 2005). The only way to differentiate between the two hypotheses was found in the dynamic verbs that were equally frequent in both forms in the input data. The predictions from the two hypotheses are presented in Table 4.

Table 4. Predictions for the L2 production in the imitation test in Thomas (2009).

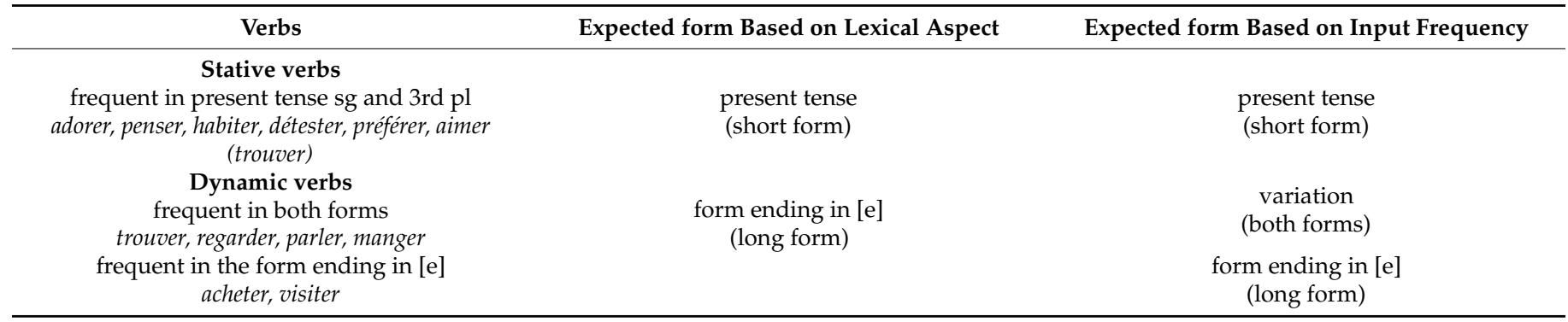

These two hypotheses were tested in an experimental design, including an imitation test. In this test, every verb was presented in the middle of a grammatical sentence, once in the present tense (parle) and once in the infinitive (veut/va parler). The learners had to listen to the pre-recorded sentence, count from one to ten in French in $4 \mathrm{~s}$ (a suppression task to avoid parroting), and then repeat the sentence they had heard. They were encouraged to say all that they remembered, even if it was only part of the sentence that they had heard. The test was administered to 33 Swedish upper secondary school learners of French at beginner-intermediate level.

The results are summarized in Figure 2. The bars show the results for each group of verbs. Overall, the learners produced many more present tense forms ( $78 \%$ ) than infinitives $(22 \%)$, a result that reflects a preference for the former. This massive transformation of the items presented in the infinitive into present tense was not expected and was interpreted as an influence of input, since classroom "beginner talk" is mainly about the here and now. 


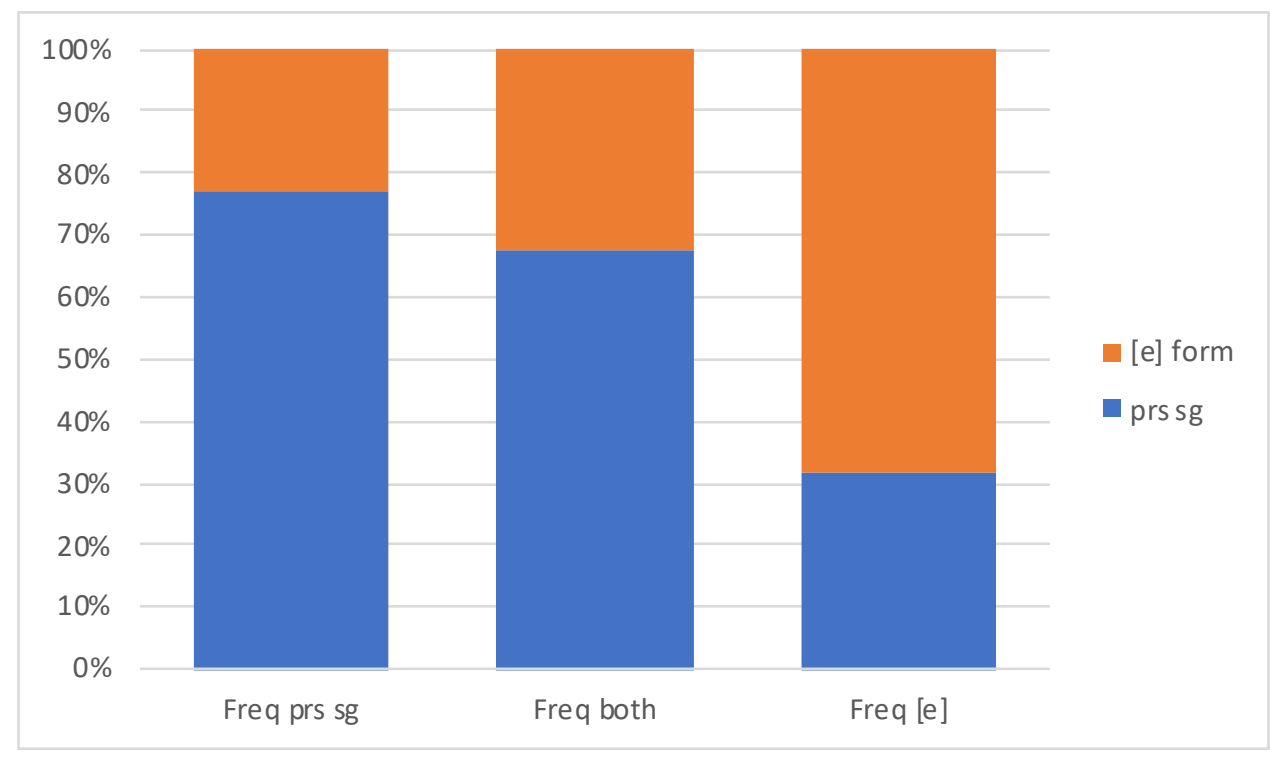

Figure 2. Production of the present tense form (e.g., / равl/) and the form ending in [e] in the imitation test within the different groups of verbs. Caption: V: verb; Freq: frequent; prs sg: present singular and 3rd plural; F: forms.

Figure 2 shows that the learners did not simply repeat all the test items. If this were the case, the result would have been $50 \%$ for all three groups of verbs ${ }^{2}$. Instead, for the (stative) verbs frequent in the present tense form in the input, the learners produced the present tense form even after a stimulus with a form ending in [e]. This is exemplified in (3): the same learner produced the same form regardless of the form (and the syntactic context) presented in the stimulus. For these verbs, we cannot differentiate the potential effect of lexical aspect or input frequency. The two factors overlap in the input as well as in the L2 learners' production.

\begin{tabular}{|c|c|c|c|c|c|c|c|}
\hline (3) & Stimulus & 9 & $\begin{array}{c}\text { En France } \\
\text { in France }\end{array}$ & $\begin{array}{l}\text { Carl } \\
\text { Carl }\end{array}$ & & $\begin{array}{l}\text { habite } \\
\text { lives }\end{array}$ & $\begin{array}{c}\text { au bord de la } \\
\text { mer. } \\
\text { at the seaside }\end{array}$ \\
\hline & P24 & & $\begin{array}{c}\text { A la } \\
\text { France }\end{array}$ & Carl & & habite & près de la mer \\
\hline & Stimulus & 10 & $\begin{array}{l}\text { En mars } \\
\text { in March }\end{array}$ & $\begin{array}{l}\text { Marie } \\
\text { Marie }\end{array}$ & $\begin{array}{l}\text { veut } \\
\text { wants }\end{array}$ & $\begin{array}{c}\text { habiter } \\
\text { to live }\end{array}$ & $\begin{array}{l}\text { à Paris. } \\
\text { in Paris }\end{array}$ \\
\hline & P24 & & A mars & Carl & & habite & à Paris \\
\hline
\end{tabular}

Similarly, at the other end of the continuum (the third bar in Figure 2), for the verbs frequent in the [e] form, a form ending in [e] was produced even after a stimulus presented with the present tense form as illustrated in (4). Unlike the transformation into present tense as in (3), where the subject was directly followed by the most frequent form of the verb, resulting in a correct present tense sentence, the absence of the semi-auxiliary in (4) results in an incorrect sentence. This can be seen as confirmation of the hypothesis that L2 learners produce the most accessible form, which corresponds to the most frequent form for a particular verb, regardless of the syntactic context. In other words, although the present tense form resembles a finite form, and the [e] form a non-finite, the status of these forms could be the same: that of a default form. However, for the dynamic verbs frequent in the [e] form, there was again a strong overlap with respect to lexical aspect and the frequency of forms in the input and in the L2 learners' production.

2 Since the research question was concerned with the form produced regardless of the syntactic context, the syntactic match with the form was disregarded. Nevertheless, $87 \%$ of the present tense forms were produced in the syntactic context for such a form as opposed to only $37 \%$ of the forms in $[\mathrm{e}]$. 


\begin{tabular}{ccccccc}
\hline (4) Stimulus & $\mathbf{2}$ & $\begin{array}{c}\text { Aujourd'hui } \\
\text { today } \\
\text { P16 }\end{array}$ & $\begin{array}{c}\text { Christine } \\
\text { Christine } \\
\text { Aujourd'hui }\end{array}$ & $\begin{array}{c}\text { Marie } \\
\text { wants }\end{array}$ & $\begin{array}{c}\text { acheter } \\
\text { to buy }\end{array}$ & $\begin{array}{c}\text { une robe. } \\
\text { adress }\end{array}$ \\
Stimulus & $\mathbf{1}$ & $\begin{array}{c}\text { Au supermarché } \\
\text { at the supermarket } \\
\text { AchetE }\end{array}$ & $\begin{array}{c}\text { Carl } \\
\text { Carl }\end{array}$ & ache robe \\
P16 & & A supermarché & Carl & buys melon. & a melon \\
& & & achetE & un melon \\
\hline
\end{tabular}

Finally, the results for the dynamic verbs frequent in both forms in the input show that the verbs were not produced according to what was expected by the hypothesis based on the verbs' lexical aspect. Instead, the learners still produced these verbs more often in the present tense form, though to a lesser extent than with the stative verbs frequent in the present tense form in the input. Example (5) illustrates the variation in the production of these verbs. It is interesting to observe that the verbs with more variation in the input were also produced with more variation by the learners, this time not only on a form level but also on a syntax level. Unlike the two other kinds of verbs, the semi-auxiliary (veut/va) was sometimes produced, resulting in mismatches on the surface form level.

\begin{tabular}{|c|c|c|c|c|c|c|c|}
\hline (5) & Stimulus & 14 & $\begin{array}{l}\text { Maintenant } \\
\text { now }\end{array}$ & $\begin{array}{l}\text { Marie } \\
\text { Marie }\end{array}$ & $\begin{array}{l}\text { veut } \\
\text { wants }\end{array}$ & $\begin{array}{l}\text { parler } \\
\text { to speak }\end{array}$ & $\begin{array}{c}\text { avec son chef. } \\
\text { with her boss }\end{array}$ \\
\hline & P26 & & Maintenant & Marie & va & parle & avec son chef \\
\hline & P08 & & Maintenant & Carine & va & parler & avec son chef \\
\hline & Stimulus & 13 & $\begin{array}{l}\text { Au travail } \\
\text { at work }\end{array}$ & $\begin{array}{l}\text { Carl } \\
\text { Carl }\end{array}$ & & $\begin{array}{l}\text { parle } \\
\text { speaks }\end{array}$ & $\begin{array}{c}\text { avec une collègue } \\
\text { with a colleague }\end{array}$ \\
\hline & P26 & & Au travail & Carl & & parle & au une collègue \\
\hline & P08 & & Au travail & Carl & & parle & avec une collègue \\
\hline
\end{tabular}

Overall, the results of this experimental study show an influence of the frequency of the surface forms in the input on the learners' production of the verb forms in this task, regardless of the syntactic context. A clear limitation of this study is that it only considered the group of regular -er verbs and, consequently, the influence of two forms.

\subsection{The Development of Third Person Plural Forms}

As mentioned in Section 3, there is no audible difference between the 3rd person singular and plural for the -er verbs, except in the cases where a verb beginning with a vowel is preceded by a subject (typically ils/elles) where the liaison between the subject and the verb is obligatory. However, the difference between 3rd singular and plural is visible in the written forms, with an -nt at the end of the form (il parle 'he speaks' and ils parlent 'they speak,' but both are pronounced / pasl/). The difference between the singular and plural forms is also audible in the four frequent and irregular verbs être 'be,' avoir 'have,' aller 'go,' and faire 'do,' for which two completely different suppletive forms are used (est-sont 'is-are,' a-ont 'has-have,' va-vont 'goes-go,' and fait-font 'does-do'). Finally, there is also a phonological difference between 3rd singular and plural for the irregular verbs with stem alternation (veut-veulent 'wants-want'). However, this difference is often phonologically not salient. In summary, there are four patterns/schemas of relationship between 3rd person singular and plural in spoken French as presented in (6) (Ågren 2017, p. 9).

1. Identical: il danse 'he dances'; ils dansent 'they dance'; il voit 'he sees'; ils voient 'they see' (-er verbs and some irregular verbs)

2. Perceivable difference through a liaison in the plural: il arrive 'he arrives'; ils arrivent 'they arrive'

3. Suppletive forms: only the four highly frequent verbs (être, avoir, faire, and aller)

4. Irregular verbs with stem alternation: il prend 'he takes'; ils prennent 'they take'; il dit 'he says'; ils disent 'they say.'

In her experimental study, Agren (2017) addressed the question of the role of input frequency on the production of subject-verb agreement in 3rd person singular and plural. The study concentrated on six verbs with stem alternation (pattern 4 above). The frequency of the two verb forms was checked in two reference corpora of spoken French: in the 
corpus of French phonology (https: / / www.projet-pfc.net, accessed on 20 February 2021) and in C-ORAL-ROM (Cresti and Moneglia 2005), as well as in the corpus of written language Lexique 3 (http:/ / www.lexique.org, accessed on 20 February 2021). For all verbs, it appeared that the 3 rd person singular was much more frequent than the 3 rd person plural (Ågren 2017, p. 13). The difference was stronger for the verbs with higher token frequency; for these verbs, the proportion of 3rd person plural was around $10 \%$ (e.g., dire 'say' and pouvoir ' $c a n$ '), while for the less frequent verbs, it could be up to $27 \%$ (e.g., comprendre 'understand' and mettre 'put'). In other words, according to the data from these corpora, the 3rd person plural is characterized by low frequency in both spoken and written French.

The results of the study are based on an imitation test taken by 42 Swedish university student learners of French at different CEFR levels (10 at A1, 10 at A2, 11 at B1, and 11 at B2 according to a Dialang test https: / / dialangweb.lancaster.ac.uk, accessed on 20 February 2021) and by a control group of 21 francophone exchange students. The six irregular verbs were presented four times each, twice in singular and twice in plural, once with subject-verb agreement (la fille boit 'the girl drinks,' les amis boivent 'the friends drink') and once with a subject-verb mismatch (la fille boivent 'the girl drink,' les amis boit 'the friends drinks'). Generally, the singular form was repeated more often by the learners, both in the grammatical and the agrammatical context, which reflects the frequency of the two forms in French and suggests that the 3rd person singular is used as default. Additionally, the number of correct imitations in the matching contexts for both forms increased with higher levels of proficiency. The learners with higher CEFR levels in French had more success, which is also an input effect in the sense that less salient phenomena need more experience in terms of exposure and practice in order to be learned (Ågren et al. 2014). However, there was no correlation between the token frequency of the different verbs and the level of correct imitation. In conclusion, the results suggest that learners overuse the pattern of the regular -er verbs on other verbs and that there is a tendency to use only one form for a given verb. This result could also be due to an influence of the learners' L1 (Swedish), which has only one form for the present tense for each verb (even the most frequent ones).

The absence of correlation with the token frequency of each specific verb could also be due to problems with the representativeness of the chosen corpora as input to the learners. This is a major issue in studies looking at the influence of input. The direct relationship between the approximate input as computed with corpora and the effective input to the learners is difficult to establish; for a discussion, see (Thomas and Ädel 2021). Indeed, it is probably an impossible task for adult learners of a language such as French and at a level other than beginner. In fact, to study the close relationship between input and output, either studies using artificial language, for example (Madlener 2018), or first exposure studies (Dimroth 2018) are necessary.

Another issue is the level of salience of the contrast between the 3rd person singular and plural forms. With subject pronouns, the contrast il/ils 'he/they-masc' and elle/elles 'she/they-fem' is only audible when the verb begins with a vowel. With nominal subjects, the contrast is with the article, which is well contrasted for the indefinite article un-une 'a' vs. des 'several' but less so for the definite article le vs. les because of the difficulty in perceiving the difference between [ə] and [e]. Given the low number of verbs with stem alternation and the very high type frequency of the regular -er verbs, the pattern of the -er verbs probably has an overshadowing effect (Ellis 2006) on other verbs (except the four highly frequent verbs). Accordingly, other verb patterns only become available to attention after a longer experience with the French type frequency effect, see (Bybee 2008). Given the opaque relationship between spoken and written language, mastery of the written forms is not necessarily helpful for oral production; the L1 phonological system could lead to misspelling (Prévost 2009).

In another study, Ågren and van de Ågren and Weijer (2013) compared the production of the same phenomenon by children aged five to six and nine to ten years old with French as their only or as one of their first language(s), or as their L2. The children performed an oral and written narrative production task where the task was the same in both modes. 
The results for the oral production showed that none of the children in the study had difficulty with subject-verb agreement in singular contexts. However, all the children overused singular forms in plural contexts, thus employing the pattern of the -er verbs on other verbs, except for the highly frequent verbs être 'be' and avoir 'have,' which were produced correctly. As in the 2017 study, the more experience the learners had with the target language, the more the plural forms were produced correctly. In other words, the L1 children were more often correct than the bilingual children, who performed better than the L2 learners. Finally, the older children in each group performed better than the younger ones (Ågren and Weijer 2013, pp. 326, 328).

The results for the written production showed a significant difference only between the L1 and the L2 children, but not between the L1 and the bilinguals, nor between the bilinguals and the L2 children. All of the children produced fewer errors for the singular than for the plural forms and also fewer errors for the verbs where there is an audible difference between 3rd person singular and plural (patterns 3 and 4 in example (6) above). In other words, the plural marker $-n t$ was more often omitted for the regular -er verbs than for the verbs with stem alternation.

The authors argue that the differing results between oral and written production are not due to frequency patterns but are inherent to the absence/presence of phonological cues between the two forms, meaning that the verbs with an audible cue for the difference between singular and plural are produced more correctly in terms of subject-verb agreement than those with silent morphology. In other words, frequency alone is not enough to explain developmental challenges in L2 acquisition; rather, other factors, such as perceptual salience, also play a role. In terms of input, the authors conclude that "a rich and continuous exposure to spoken and written language is a prerequisite for a successful acquisition of these complex aspects of the French language" (Ågren and Weijer 2013, p. 332).

\subsection{The Development of Past Tense}

The presentation of the French verb morphology in Section 3 underlined the fact that the two past tense forms are homophonous for the -er verbs. This means that the formfunction association specific to the two past tense forms is phonologically not salient for $90 \%$ of French verbs. This suggests that the learners might need more input with irregular verbs in order to notice the specific functions of the two past tense forms.

Earlier research on the L2 learning of French at different ages has shown that the development of French past tense is rather slow in the sense that there are still difficulties even at advanced levels of proficiency (Bartning and Schlyter 2004; Kihlstedt and Schlyter 2009). L2 learners of French mainly use the passé composé or a bare past participle and the present tense. The imparfait is mainly restricted to était 'was' and avait 'had,' which are the two verbs most frequently used in this tense in French (Kihlstedt and Schlyter 2009).

In their studies, Nicoladis et al. (2007) and Paradis et al. (2011) examined French regular and irregular verbs separately. The results show that both French monolingual and bilingual children have more difficulties in producing the correct form of the past participle for irregular than for regular verbs. For irregular verbs, the past participle is often replaced by the infinitive or by a form inspired by the homophonous form of the -er verbs. In these studies, the correct production of irregular verbs was correlated to the amount of exposure to French, with more exposure giving better results, suggesting that the frequency of forms in the input may play an important role in the acquisition of verb morphology.

A study with similar results has been conducted with L2 children (Thomas 2014a). The production of French verbs in the past tense by children who were at beginner to intermediate levels was correct in more than $90 \%$ of the cases for the regular verbs (11 verbs), a proportion that was reached for only 2 of the 10 irregular verbs studied (partir 'leave' and venir 'come'). These results suggest that input frequency plays a role in the production of the past tense. The high proportion of correct past tense marking for regular verbs by L2 children, even with verbs frequent in present tense, can be explained as an effect of type 
frequency. The systematic association between past tense and a form in [e] (see Table 3) in regular verbs is a pattern that L2 children seem to grasp quickly. On the other hand, correct past tense marking is more difficult with irregular verbs, since the learners are dependent on token frequency; that is, on the number of times they encounter a specific form.

The study by Nicoladis and colleagues (2007) is particularly interesting because they empirically established the frequency of English and French past tense in native spoken and written data. They counted the number of different verbs (types) and of tokens in production data from two L1 French speaking children in the CHILDES corpus (MacWhinney 2002): Philippe and Grégoire. They randomly chose three sessions from the data and counted the number of past tense verbs used by the adults in the presence of the children (Nicoladis et al. 2007, p. 240). The results showed that regular verbs constituted the majority of verbs both in the number of different verbs and of tokens in the input to both French children. They then compared these data with data from two cartoons, and again, found that French regular verbs are "on average, very high in token frequency relative to English verbs and slightly higher in type frequency" (Nicoladis et al. 2007, p. 241). Again, French regular verbs were more frequent than irregular verbs, both in tokens and in types. This means not only that the -er verb pattern is dominant but that these regular verbs are among the most frequently used verbs in French.

Another interesting question is the frequency of past tense forms compared to other common forms in spoken French. Collins et al. (2009), for example, showed that the English regular past tense was quite infrequent in the input provided to the learners in the study. In a small-scale study, Thomas (2014b) examined the frequency of 15 common regular verbs and 15 common irregular verbs in a range of corpora that could be used as a proxy for L2 learner input. Except for the data from the textbook, the same corpora were used as in Thomas (2009) but with the addition of the following:

- The adult interlocutors (MOT, CHR, FAT, MAD) in interaction with the L1 child Philippe aged from 2.1 to 3.3 years (corpus Leveille, 26 recordings) and the L1 child Grégoire aged from 1.9 to 2.5 years (corpus Champaud, 33 recordings) in CHILDES (MacWhinney 2002).

- The adult interlocutors in conversation with five children learning L2 French in immersion in Sweden (Ågren et al. 2014), 27 recordings of 20-30' each.

Again, the compilation included all the forms presented in Table 3 above. The results are illustrated in Table 5.

Table 5. Distribution of the most frequent forms in 15 regular and 15 irregular verbs in five corpora of spoken French.

\begin{tabular}{ccc}
\hline Context & $\begin{array}{c}\text { Regular -er Verbs } \\
\text { Proportion (Tokens) }\end{array}$ & $\begin{array}{c}\text { Irregular Verbs } \\
\text { Proportion (Tokens) }\end{array}$ \\
\hline Present sg+3pl & $48 \%(2950)$ & $60 \%(7124)$ \\
Infinitive & $23 \%(1445)$ & $16 \%(1922)$ \\
Present 2nd plural & $5 \%(324)$ & $5 \%(542)$ \\
imparfait & $6 \%(372)$ & $5 \%(630)$ \\
Past participle & $18 \%(1110)$ & $14 \%(1655)$ \\
Sum forms ending in [e] & $52 \%(3251)$ & $10 \%(1172)$ \\
(grey zone) & $\mathbf{6 2 0 1}$ & $\mathbf{1 1 , 8 7 3}$ \\
Sum & &
\end{tabular}

The results of this analysis show that the present tense (singular and 3rd person plural) is the most frequent tense for both kinds of verbs. It also appears that the imparfait is very rare (5-6\%) and that the past participle is less frequent (14-18\%) than the infinitive (around 16-23\%). This suggests that the past tense forms are less available in the input to learners than the other forms. It is also interesting to note that there are proportionally more infinitives and past participles for regular verbs than for irregular verbs. However, given the homophony between the two forms for the -er verbs, the relationship between form 
and function is not made salient with these verbs. In summary, the input to the learner, as measured here, is probably insufficient for the learners to notice the differences between the homophonous forms for the regular -er verbs. The combination of the variation of different forms for irregular verbs, making each specific form infrequent, and of the dominance of the present tense for these verbs probably contributes to the slow development of L2 French verb morphology.

\section{Conclusions}

The aim of this article was to present the French verb morphological system in terms of frequency, salience, and form-function association and to show its implications for L2 input processing. This article also presented a review of studies that examined the relationship between input characteristics and the L2 development of verb morphology. The studies presented suggest an influence of input on L2 production and confirm that one of the difficulties inherent in learning French can be related to the very high type frequency of the regular -er verbs. Moreover, unlike other languages, such as English, the -er verbs are also frequent in tokens. Thus, the different forms of irregular verbs (other than the four most frequent verbs) are scarce in the learners' input. Additionally, it seems that irregular verbs are mainly used in the present tense, which adds to the low level of salience of the two past tense forms in the input. To a learner, oral French input suggests two frequent forms: a singular present tense form on the one hand, and a multifunctional form ending in [e] on the other hand. One avenue of research worth pursuing would be to study the effect of an input enriched with "common" irregular verbs in order to see whether such input could facilitate the learning of French verb morphology.

This article focused on input characteristics as studied in corpora and on the influence of input on the acquisition of L2 French. However, there are many different ways of investigating the influence of input, as well as other factors that play a role in L2 language acquisition. For example, the study of Agren et al. (2014) showed that there is a combined effect of age of onset, the input situation of the learners in terms of active access to the target language, and the linguistic characteristics of the morphosyntactic phenomena under investigation. Additionally, as underlined by Howard (2011), input is not a monolithic entity but consists of several layers. Important factors include the role of implicit and explicit approaches to L2 teaching and the context of learning, such as traditional classroom teaching, immersive approaches, or "in the wild" (see Cadierno and Eskildsen 2015).

Recently, the issue of input in French L2 has grown in importance in the field of French language teaching. The role of corpora of authentic language as input to L2 learners is a current and dynamic trend of research. According to Boulton (2017), early results show a positive effect of this kind of input on the development of (academic) written language as well as on a better comprehension of the target language (for example, on the use of frequent discourse markers). However, we know very little about the effect of corpora on the development of oral production in the long run. Finally, input quality has mainly been conceptualized/operationalized as the quality of the environment, as in the work of Paradis and colleagues, but there are very few attempts at discussing the quality of input material, for example in obligatory school settings (see, e.g., Kasprowicz and Marsden 2018; Sakata 2019).

Funding: This research received no external funding.

Acknowledgments: Many thanks to the reviewers for their very useful comments on an earlier version of this article and to Anna Auger for proofreading and improving the quality of the text.

Institutional Review Board Statement: Not applicable.

Informed Consent Statement: Not applicable.

Data Availability Statement: Not applicable.

Conflicts of Interest: The author declares no conflict of interest. 


\section{References}

Ågren, Malin. 2017. Étude expérimentale sur le traitement de l'accord sujet-verbe en nombre en FLE. Bulletin suisse de Linguistique appliquée 105: 69-86.

Ågren, Malin, and Joost van de Weijer. 2013. Input Frequency and the Acquisition of Subject-Verb Agreement in Number in Spoken and Written French. Journal of French Language Studies 23: 311-33. [CrossRef]

Ågren, Malin, Jonas Granfeldt, and Anita Thomas. 2014. Combined Effects of Age of Onset and Input on the Development of Different Grammatical Structures. A Study of Simultaneous and Successive Bilingual Acquisition of French. Linguistic Approaches to Bilingualism 4: 462-93. [CrossRef]

Andersen, Roger W. 2002. The Dimensions of "Pastness". In The L2 Acquisition of Tense-Aspect Morphology. Edited by R. Salaberry and Yasuhiro Shirai. Amsterdam and Philadelphia: John Benjamins, pp. 70-105.

Andersen, Roger W., and Yasuhiro Shirai. 1994. 'Discourse Motivations for Some Cognitive Acquisition Principles'. Studies in Second Language Acquisition 16: 133-56. [CrossRef]

Barlow, Michael, and Suzanne Kemmer. 2000. Introduction: A Usage-Based Conception of Language. In Usage Based Models of Language. Edited by Michael Barlow and Suzanne Kemmer. Stanford: CSLI Publications, pp. vii-xxviii.

Bartning, Inge, and Suzanne Schlyter. 2004. Itinéraires Acquisitionnels et Stades de Développement En Français L2. Journal of French Language Studies 14: 281-99. [CrossRef]

Bartning, Inge, Fanny Forsberg, and Victorine Hancock. 2009. Resources and Obstacles in Very Advanced L2 French: Formulaic Language, Information Structure and Morphosyntax. EUROSLA Yearbook 9: 185-211. [CrossRef]

Behrens, Heike, and Stefan Pfänder. 2016. Experience Counts Frequency Effects in Language Acquisition, Language Change, and Language Processing. Berlin: De Gruyter.

Boulton, Alex. 2017. Corpora in Language Teaching and Learning. Language Teaching 50: 483-506. [CrossRef]

Bybee, Joan L. 1995. Regular Morphology and the Lexicon. Language and Cognitive Processes 10: 425-55. [CrossRef]

Bybee, Joan L. 2008. Usage-Based Grammar and Second Language Acquisition. In Handbook of Cognitive Linguistics and Second Language Acquisition. Edited by Peter Robinson and Nick C. Ellis. New York: Routledge, pp. 216-36.

Cadierno, Teresa, and Søren Wind Eskildsen, eds. 2015. Usage-Based Perspectives on Second Language Learning. Applications of Cognitive Linguistics 30. Berlin and Boston: De Gruyter Mouton.

Collins, Laura, Pavel Trofimovich, Joanna White, Walcir Cardoso, and Marlise Horst. 2009. 'Some Input on the Easy/Difficult Grammar Question: An Empirical Study'. Modern Language Journal 93: 336-53. [CrossRef]

Cresti, Emanuela, and Massimo Moneglia. 2005. C-ORAL-ROM: Integrated Reference Corpora for Spoken Romance Languages. Amsterdam: John Benjamins.

Dimroth, Christine. 2018. 'Beyond Statistical Learning: Communication Principles and Language Internal Factors Shape Grammar in Child and Adult Beginners Learning Polish Through Controlled Exposure'. Language Learning 68: 863-905. [CrossRef]

Ellis, Nick C. 2006. Selective Attention and Transfer Phenomena in L2 Acquisition: Contingency, Cue Competition, Salience, Interference, Overshadowing, Blocking, and Perceptual Learning. Applied Linguistics 27: 164-94. [CrossRef]

Ellis, Nick C., Ute Römer, and Matthew Brook O'Donnell. 2016. Usage-Based Approaches to Language Acquisition and Processing: Cognitive and Corpus Investigations of Construction Grammar. Chichester: Wiley.

Fayol, Michel, and Jean-Pierre Jaffré. 2008. Orthographier. Paris: Presses Universitaires de France.

Flyman Mattsson, Anna. 2003. Teaching, Learning, and Student Ouput. A Study of French in the Classroom. Ph.D. Thesis, Lund University, Lund, Sweden.

Gass, Susan M. 2015. Comprehensible Input and Output in Classroom Interaction. In The Handbook of Classroom Discourse and Interaction. Edited by Numa Markee. Chichester: John Wiley \& Sons Inc, pp. 182-97.

Giroud, Anick, and Christian Surcouf. 2016. De «Pierre, combien de membres avez-vous?» à «Nous nous appelons Marc et Christian»: Réflexions autour de l'authenticité dans les documents oraux des manuels de FLE pour débutants. SHS Web of Conferences 27: 07017. [CrossRef]

Goldschneider, Jennifer M., and Robert M. DeKeyser. 2001. Explaining the "Natural Order of L2 Morpheme Acquisition" in English: A Meta-Analysis of Multiple Determinants. Language Learning 51: 1-50. [CrossRef]

Howard, Martin. 2011. Input Perspectives on the Role of Learning Context in Second Language Acquisition. An Introduction to the Special Issue. International Review of Applied Linguistics in Language Teaching 49: 71-82. [CrossRef]

Kasprowicz, Rowena, and Emma Marsden. 2018. Towards Ecological Validity in Research into Input-Based Practice: Form Spotting Can Be as Beneficial as Form-Meaning Practice. Applied Linguistics 39: 886-911. [CrossRef]

Kihlstedt, Maria, and Suzanne Schlyter. 2009. Emploi de La Morphologie Temporelle En Français L2 : Étude Comparative Auprès d'enfants Monolingues et Bilingues de 8 à 9 Ans. Acquisition et Interaction En Langue Étrangère AILE 1: 89-115. [CrossRef]

Labeau, Emmanuelle. 2005. Beyond the Aspect Hypothesis: Tense-Aspect Development in Advanced L2 French. EUROSLA Yearbook 5: 77-101. [CrossRef]

MacWhinney, Brian. 2002. The CHILDES Project: Tools for Analyzing Talk. Mahwah: Lawrence Erlbaum Associates.

Madlener, Karin. 2018. Do Findings from Artificial Language Learning Generalize to Second Language Classrooms? In Usage-Inspired L2 Instruction. Researched Pedagogy. Edited by Andrea E. Tyler, Lourdes Ortega, Mariko Uno and Hae In Park. Amsterdam and Philadelphia: John Benjamins, pp. 211-34. 
Meunier, Fanny, and William Marslen-Wilson. 2004. Regularity and Irregularity in Frenchverbal Inflection. Language and Cognitive Processes 19: 561-80. [CrossRef]

Nicoladis, Elena, Andrea Palmer, and Paula Marentette. 2007. The Role of Type and Token Frequency in Using Past Tense Morphemes Correctly. Developmental Science 10: 237-54. [CrossRef] [PubMed]

Paradis, Johanne. 2010. Bilingual Children's Acquisition of English Verb Morphology: Effects of Language Exposure, Structure Complexity, and Task Type. Language Learning 60: 651-80. [CrossRef]

Paradis, Johanne, Elena Nicoladis, Martha Crago, and Fred Genesee. 2011. Bilingual Children's Acquisition of the Past Tense: A Usage-Based Approach. Journal of Child Language 38: 554-78. [CrossRef]

Perdue, Clive, ed. 1993. Adult Language Acquisition: Cross-Linguistic Perspectives. Volume 2. The Results. Cambridge: Cambridge University Press.

Prévost, Philippe. 2009. The Acquisition of French. In The Development of Inflectional Morphology and Syntax in L1 Acquisition, Bilingualism, and L2 Acquisition. Amsterdam: John Benjamins.

Prévost, Philippe, and Lydia White. 2000. Missing Surface Inflection or Impairment in Second Language Acquisition? Evidence from Tense and Agreement. Second Language Research 16: 103-33. [CrossRef]

Sakata, Naoki. 2019. Profiling Vocabulary for Proficiency Development: Effects of Input and General Frequencies on L2 Learning. System 87: 102167. [CrossRef]

Schmidt, Richard. 2001. Attention. In Cognition and Second Language Instruction. Edited by Peter Robinson. Cambridge: Cambridge University Press, pp. 3-32.

Thomas, Anita. 2009. Les Apprenants Parlent-Ils à l'infinitif? Influence de l'input Sur La Production Des Verbes Par Des Apprenants Adultes Du Français. Études romanes de Lund 87. Lund: Lund University (Sweden). Available online: http://lup.lub.lu.se/ search/ws / files/5369358/1473802.pdf (accessed on 20 February 2021).

Thomas, Anita. 2014a. C'est La Faute de l'input! Fréquence Des Formes et Biais Distributionnels. Presented at the The Expression of Temporality by L2 Learners of French and English, Acquisition of Time, Aspect, Modality, Montpellier, France, May $22-24$.

Thomas, Anita. 2014b. Le Rôle de l'Aspect Lexical et de la Fréquence des Formes dans l'Input sur la Production des Formes du Passé par des Enfants Apprenants du Français L2 en Début d'Acquisition. The Canadian Modern Language Review/La Revue Canadienne Des Langues Vivantes 70: 1-27. [CrossRef]

Thomas, Anita, and Annelie Ädel. 2021. Input. In The Routledge Handbook of Second Language Acquisition and Corpor. Edited by Nicole Tracy-Ventura and Magali Paquot. New York: Routledge, pp. 267-79.

Walter, Henriette. 1982. Enquête Phonologique et Variétés Régionales Du Français. Paris: Presses Universitaires de France. 